\title{
Interval Type-2 Fuzzy Super SBM Network DEA for Assessing Sustainability Performance of Third-Party Logistics Service Providers Considering Circular Economy Strategies in the Era of Industry 4.0
}

\author{
Mahsa Pishdar ${ }^{1}$, Masoumeh Danesh Shakib ${ }^{2}$, Jurgita Antucheviciene ${ }^{3, *(D)}$ and Arvydas Vilkonis ${ }^{3}$ \\ 1 Department of Industrial and Technology Management, Faculty of Management and Accounting, \\ College of Farabi, University of Tehran, Qom 17469-37181, Iran; pishdarmahsa@gmail.com \\ 2 Industrial Management Department, Qazvin Branch, Islamic Azad University, Qazvin 34185-1416, Iran; \\ m.shakib@qiau.ac.ir \\ 3 Department of Construction Management and Real Estate, Vilnius Gediminas Technical University, \\ Sauletekio al. 11, LT-10223 Vilnius, Lithuania; arvydas.vilkonis@stud.vgtu.lt \\ * Correspondence: jurgita.antucheviciene@vilniustech.lt
}

Citation: Pishdar, M.; Danesh Shakib, M.; Antucheviciene, J.; Vilkonis, A. Interval Type-2 Fuzzy Super SBM Network DEA for Assessing Sustainability Performance of Third-Party Logistics Service Providers Considering Circular Economy Strategies in the Era of Industry 4.0. Sustainability 2021, 13, 6497. https://doi.org/10.3390/ su13116497

Academic Editor: Florian Kellner

Received: 29 April 2021

Accepted: 28 May 2021

Published: 7 June 2021

Publisher's Note: MDPI stays neutral with regard to jurisdictional claims in published maps and institutional affiliations.

Copyright: (c) 2021 by the authors. Licensee MDPI, Basel, Switzerland. This article is an open access article distributed under the terms and conditions of the Creative Commons Attribution (CC BY) license (https:// creativecommons.org/licenses/by/ $4.0 /)$.

\begin{abstract}
Stakeholders are increasingly aware of the aspect of sustainability, and the fact that the circular economy facilitates the achievement of sustainable development goals. They place pressure on supply chains to become sustainable, and for this reason, third-party logistics (3PL) service providers, as specialized professionals, play a vital role in sustainable supply chain management. Although developments in technology in the era of Industry 4.0 have been effective at directing 3PLs along the path towards sustainability, integrated management of forward and reverse logistics systems in order to achieve a circular economy and to become sustainable remains a problem, even in developed countries. However, benchmarking and using the experiences of others can help to speed up this path at a minimal cost. An interval type-2 fuzzy super-slack-based measure network DEA was developed to make such benchmarking possible. Governance style, staff behavior, environmental management systems, and social elements are considered, alongside the principles of the circular economy, in order to compare the sustainability performance of 17 3PLs with respect to different aspects through the application of the developed DEA model. Proper benchmarking with respect to strategies and operations of the 3PLs that are recognized as efficient makes it possible for these 3PLs to overcome obstacles and progress at a lower cost. The results show that 3PLs do not have a comprehensive sustainability strategy that is coordinated with an overall vision of the total supply chain. An investigation into the development of a framework with multiple steps for the guidance of 3PLs, as well as the whole supply chain, towards sustainability in the Industry 4.0 era would be a fruitful next study.
\end{abstract}

Keywords: circular economy; data envelopment analysis; Industry 4.0; reverse logistics; sustainability; third-party logistics providers

\section{Introduction}

In light of climate change and the COVID pandemic, the time to redesign the global economy in order to take robust steps towards sustainability has arrived. In the recent past, brands could introduce their products as being sustainable purely on the basis that their packaging was recyclable. However, a single green feature cannot guarantee sustainability anymore [1]. Nowadays, brands have to put consistent efforts into developing integrated strategies to make the whole supply chain sustainable [2,3]; only under such conditions will their stakeholders be convinced that the brand is committed to principles of sustainability, taking into account goals from all of the three dimensions of economic, environmental, and social matters, in addition to considering customer and stakeholder requirements [4,5]. 
The circular economy, as an alternative to the traditional linear economy, seeks to keep resources in the supply chain for as long as possible, extracting the maximum value throughout their life cycle, and then recovering and regenerating products and materials through the use of reverse logistics systems, in this way helping the supply chain to become more sustainable. The circular economy is gaining increasing attention in the fast-moving consumer goods (FMCG) industry as a way of achieving a more sustainable use of natural resources, and environment management systems could certainly not have been developed without the assistance of reverse logistics systems. Reverse logistics is a crucial creator of strategic value in supply chains with the aim of achieving a sustainable environment and promoting a circular economy [2,6,7]. For this reason, the integration of forward and reverse logistics systems is important for assessing the sustainability performance of 3PLs.

Reverse logistics, as the process of moving materials from their final destination in order to recapture a degree of value or to ensure proper disposal was not traditionally regarded as being important, as it contains only a small portion of the functions of the overall services provided by logistics system providers [8]. Nowadays, consumers' expectations with respect to high performance, high volume, and lower price have been increased, all without the willingness to compromise on quality. It is also notable that separate logistics flows mean putting financial and non-financial aspects into separate physical facilities and systems. The recent combination of these flows adds complexities to supply chain management, considering their differences in nature, and making the right decisions with respect to the configuration of forward and reverse logistics systems can create substantial value $[9,10]$. The reverse flow faces uncertainties with respect to flow size fluctuations, transportation planning, warehousing, marketing support, discard capacity, information systems, and any other conditions that could reduce the possibility of standardization and lead to an increase in manual labor efforts. However, forward logistics can be standardized with more certainty [11,12]. These factors have encouraged business organizations to outsource their logistics services to third-party logistics (3PL) service providers. Outsourcing logistics functions can lead to a competitive advantage when the 3PLs are capable and experienced; otherwise, the public image and reputation of the business organization could be degraded to a large extent. Therefore, the selection process of 3PLs and the assessment of their performance must be undertaken with a great deal of care, especially when the sustainability of the supply chain is of great importance [13]. The functions of 3PLs can determine the levels of environmental, economic, social, and operational performance of the whole supply chain [14]. In addition, it is indisputable that designing an integrated forward and reverse logistics system is of great complexity and requires the necessary expertise, infrastructure, technology, and time management, which is, even in developed countries, difficult to achieve, requiring scientific diagnosis [12]. Considering these mentioned issues, this question will shape how assessment of the sustainability performance of 3PLs is possible. Based on the answer to this question and the strengths and weaknesses that are determined by such assessment, the improvement roadmap will be developed.

To fill this gap, the current study aims to help 3PLs in Iran, as a developing country that is struggling with various challenges, such as the lack of an efficient governance system, to take steps towards sustainability more easily. These 3PLs are providing services in FMCG industry which has its own especial logistics challenges, such as corruption of products and lack of customer loyalty. In addition, FMCG companies account for the notable share of waste and greenhouse emissions and circular economy transition is crucial to them. Since the first step to take the path towards sustainability is to investigate current potentials and challenges of 3PLs; an integrated set of sustainability criteria that have the utmost impact on the level of 3PL service provider's performance of 3PLs will be determined by the literature review in Section 2 and will be finalized by gaining experts' opinions after that. Consideration of the technological enhancement of Industry 4 and circular supply chains together along with other criteria to assess the sustainability performance of 3PLs does not have much history. However, this is not the only highlight of current paper. 
DEA is considered one of the common methods for measuring performance and has been used to evaluate a part of the supply chain performance or the total performance of it. Kalantary and Farzipoor Saen (2019) [15] study about supply chain assessment; Zhou et al. (2019) [16] study about developing the sustainable supply chain; Rodrigues et al. (2018) [17] study that considers efficiency of specialized 3PL providers in an emerging economy are among the different studies that used DEA method to assess the performance of the supply chain or an especial part of it by the use of fuzzy theory [18]. That is why especial data envelopment analysis (DEA) model will be developed to assess sustainability performance of 17 Iranian 3PLs in the most appropriate way. Development of type-2 fuzzy slack-based management network data envelopment analysis (SBM-NDEA) is another highlight of current paper and worthful by itself. Such assessment helps to rank the current level of sustainability performance of 3PLs and benchmarking will be possible for the 3PLs in this way. Such features can easily discriminate this study from the previous similar ones.

The following sections of the paper is as follows: literature will be reviewed in Section 2 and the initial set of criteria to assess the sustainability performance of the 3PLs will be determined. Then, the material and methods will be explained in Section 3. After that, results are presented in Section 3, and the discussion will be done in Section 4. At last, the conclusion is provided in Section 5 to summarize the results and suggest future research domains.

\section{Literature Review}

\subsection{Supply Chain Management in Industry 4 Era}

Since the sustainability of the supply chain is essential, it is important to understand the market vulnerabilities and the importance of making full use of limited resources. Many organizations evaluate their activities throughout the supply chain in order to integrate sustainability effectively into various practices, and integrate reverse logistics activities in each part of the supply chain. Technology would certainly be of great benefit. Industry 4 is the last industrial revolution, originating in 2011 from a project in the high-tech strategy of the German government. It is aimed to make a linkage between real objects and virtual objects by use of information networks to synchronize digital, physical, and biological systems and promoting the computerization of manufacturing. In this way, decentralized and real time decisions are made through the whole system [19-21].

The application of the concepts mentioned in the Industry 4 to supply chain operations is named Supply Chain 4 . Supply Chain 4 is going to be smarter, more efficient and productive, safer, and more sustainable by the use of new business models and innovative technologies in order to bring customer satisfaction. The consideration of physical and cybernetic systems at the same time causes new opportunities to enhance the level of sustainability in the supply chains $[20,22]$. Industry 4 advancements in technology not only fosters sustainable supply chain implements that can maximize economic values but also reduce environmental impacts and plays a role in social development [23-25]. Industry 4 can foster the impact of the circular economy in supply chain management by increasing waste disposal; promoting remanufacturing; enhancing the efficiency of critical resources such as water, energy, gas, and $\mathrm{CO}_{2}$; and improving business models and the mission of companies [26].

However, each coin has the other side too. Organizations are finding difficulties in prioritizing sustainability in the global markets due to many barriers in the era of Industry 4 and the circular economy. Some obstacles include lack of a skilled workforce that understands Industry 4 principles, ineffective legislation and control systems, poor performance framework, and short-term corporate visions and goals. Ineffective strategies for the integration of Industry 4 with sustainability measures, and lack of financial budgets for Industry 4 initiatives are among the most important ones. Sustainable operations will be fostered through the utilization of improved knowledge of Industry 4 and the circular economy [27]. 


\subsection{PLs Role in Sustainable Supply Chain Management}

Industry 4 also has its effect on logistics systems and created a Logistic 4 concept which operates under the same principles. It makes use of smart vehicles and other transport systems with the aim of creating a fully networked integrated supply stream [7]. However, transport planning is still complicated and addresses specific problems. Improving accessibility is still noticeable. Other goals, such as safety, health considerations, reducing adverse environmental impacts, even equity enhancement are all valuable too. This complexity makes a tendency to transfer side activities of the supply chain to the specialized companies known as third-party logistics (3PL) providers. 3PLs take responsibility of various transportation operations such as delivery of goods, storage, revenue, assembly, loading, labelling, repacking, and distribution. In addition, such companies must be integrated with other components of the supply chain through data collection and transmission. Their end goal is to optimize the logistics processes, minimizing operating costs, enhancement of environmental and social performance while improving the service quality [28,29]. However, the especial characteristics of some products such as food, vegetables, and medicine need the cold chain and the correct temperature must be kept to preserve the quality of products from the moment of production to the time at which they reach the end consumer. These characteristics even increase the specialized need to deal with the transport network [17].

Prioritization of such goals shapes the transportation governance system [30]. Sustainability approach helps management to consider economic, social, and environmental issues simultaneously, and prioritize each goal considering especial situations. Management commitment is an essential item to integrate the whole supply chain and this commitment is shown through setting a clear sustainability vision; obeying the related standards and legislations and enhancement of supply chain transparency [18,31].

Logistics 4 also makes it possible to implement new strategies such as omni-channel strategy to satisfy customer demands by synchronize inventory, logistics, and distribution processes across all sales channels. Omni-channel retailing creates an integrated process providing a cohesive outlook of a product or service to the consumer containing the issues of purchase, return, and exchange in each sale channel. Wide ranges of technologies should be used to trace and track each consumer behavior to provide a personalized shopping experience. This enhances customer satisfaction and improves the sustainability of the supply chain through sustainable consumption and production. Since fewer brick and mortal stores are used and fewer inventories are distributed through the supply chain, use of energy, and use of material, product, packaging, and even the waste cost will become less [32].

Set of criteria to evaluate 3PLs, sustainability performance containing features of Industry 4 is specified in Table 1 based on literature review.

Table 1. Criteria for performance evaluation of 3PL providers.

\begin{tabular}{|c|c|c|c|}
\hline Criteria & Sub-Criteria & Description & $\begin{array}{l}\text { Some of the } \\
\text { References }\end{array}$ \\
\hline \multirow{3}{*}{ Governance } & $\begin{array}{l}\text { Management } \\
\text { commitment to shape } \\
\text { effective SCM } 4.0 \\
\text { framework }\end{array}$ & $\begin{array}{l}\text { Determination of sustainability vision and its publication while } \\
\text { promoting shared values in the field of sustainability in the } \\
\text { workplace and encourage employees to advance the principles } \\
\text { of sustainability considering green governance principles }\end{array}$ & {$[6,33-40]$} \\
\hline & $\begin{array}{l}\text { Coordination and } \\
\text { cooperation among } \\
\text { supply chain } \\
\text { members }\end{array}$ & $\begin{array}{l}\text { Effective cooperation is helpful to set sustainability principles } \\
\text { through the whole supply chain and gain of integration. } \\
\text { Network of machines, workers, and systems should be } \\
\text { implemented in the whole supply chain to shape Industry } 4 \text { logic }\end{array}$ & {$[21,41-46]$} \\
\hline & $\begin{array}{l}\text { Technology } \\
\text { innovation }\end{array}$ & $\begin{array}{l}\text { The capability to adopt innovative and internet-based } \\
\text { approaches to face the objectives of business partners and } \\
\text { increase market penetration and clearance (E-commerce; } \\
\text { Enterprise resource planning, Online status tracking systems, } \\
\text { IOT, IOS, IOP and big data, or application of machine learning } \\
\text { algorithms are some of the key technologies of Industry } 4\end{array}$ & [45-48] \\
\hline
\end{tabular}


Table 1. Cont.

\begin{tabular}{|c|c|c|c|}
\hline Criteria & Sub-Criteria & Description & $\begin{array}{l}\text { Some of the } \\
\text { References }\end{array}$ \\
\hline \multirow{5}{*}{ Governance } & Data Management & $\begin{array}{l}\text { In Industry } 4 \text { all the processes related to data, information and } \\
\text { knowledge are changed considering the inharmonious nature of } \\
\text { raw data. So, importance of data integration and management is } \\
\text { out of question }\end{array}$ & {$[44,46]$} \\
\hline & $\begin{array}{l}\text { Legislations and } \\
\text { standards }\end{array}$ & $\begin{array}{l}\text { Stakeholder management considering and external } \\
\text { accountability, transparency and information sharing, and } \\
\text { cooperation with other supply chain parts to enhance } \\
\text { sustainability of the whole chain via shared strategies }\end{array}$ & [48-51] \\
\hline & $\begin{array}{l}\text { Commitment to the } \\
\text { transparency of the } \\
\text { supply chain }\end{array}$ & $\begin{array}{l}\text { Stakeholder management considering internal and external } \\
\text { accountability, transparency and information sharing, and } \\
\text { cooperation with other supply chain parts to enhance } \\
\text { sustainability of the whole chain via shared strategies }\end{array}$ & {$[48,50,51]$} \\
\hline & $\begin{array}{l}\text { Omni-channel } \\
\text { strategy commitment }\end{array}$ & $\begin{array}{l}\text { Seeking to synchronize inventory, logistics and distribution } \\
\text { functions across all sales channels to meet consumer demand }\end{array}$ & {$[21,52,53]$} \\
\hline & Resilience & $\begin{array}{l}\text { A risk management approach concerned with how system } \\
\text { prevent or deals with service disturbance; this is done paying } \\
\text { attention to flexibility }\end{array}$ & {$[13,35,48,54]$} \\
\hline \multirow{4}{*}{ Economic } & Quality & Seeking to define and update the values of the customer & {$[13,48,55-57]$} \\
\hline & Financial capability & $\begin{array}{l}\text { Realized revenue less total cost per period of the organization } \\
\text { and its reputation to obtain external financial resources }\end{array}$ & {$[12,13,48]$} \\
\hline & Lead time & $\begin{array}{l}\text { All the processing time, transit time, etc. needed to handle the } \\
\text { inventory to the customer }\end{array}$ & {$[12,48]$} \\
\hline & Delivery and Service & $\begin{array}{l}\text { Value-added services that could be pre- and post-sale Pre- and } \\
\text { post-sale services to customer considering problem resolution } \\
\text { ability while commitment to continuous improvement }\end{array}$ & {$[12,48,55]$} \\
\hline \multirow{8}{*}{$\begin{array}{l}\text { Environment } \\
\text { - Circular Economy } \\
\text { elements are } \\
\text { shown in this } \\
\text { section }\end{array}$} & Recycle & $\begin{array}{l}\text { Gentle logistics service by looking toward a material-recycling } \\
\text { society in compliance with all regulations }\end{array}$ & {$[13,48,55]$} \\
\hline & Disposal & $\begin{array}{l}\text { Dealing with scrap, waste and refuse to prevent environmental } \\
\text { pollution and waste of resources }\end{array}$ & {$[13,48,55,56]$} \\
\hline & $\begin{array}{l}\text { Green } \\
\text { Remanufacturing }\end{array}$ & $\begin{array}{l}\text { Manufacturing practices that do not harm the environment } \\
\text { during any phases. It involves green redesign of products, use of } \\
\text { environmentally friendly raw materials, eco-friendly packing, } \\
\text { distribution, and reuse after end of life of product. It is totally } \\
\text { related to green reverse logistics }\end{array}$ & {$[13,48,55,56]$} \\
\hline & Green Technology & $\begin{array}{l}\text { Technology that is invented to mitigate or reverse the effects of } \\
\text { human activities on the environment. For water transportation } \\
\text { for instance, it can be about hybrid-electrical propulsion systems } \\
\text { in order to replace diesel engines and for road transportation it is } \\
\text { about liquefied natural gas }\end{array}$ & {$[13,48,57]$} \\
\hline & $\begin{array}{l}\text { Environment } \\
\text { protection } \\
\text { certifications }\end{array}$ & $\begin{array}{l}\text { The Eco-Management and Audit Scheme (EMAS) and ISO } 14001 \\
\text { are two of such certifications }\end{array}$ & {$[13,48,57]$} \\
\hline & $\begin{array}{l}\text { Eco-design } \\
\text { production }\end{array}$ & $\begin{array}{l}\text { Manufacturing sustainable products to satisfy consumers } \\
\text { considering logistics role }\end{array}$ & {$[13,48]$} \\
\hline & $\begin{array}{l}\text { Greenhouse gas } \\
\text { emissions }\end{array}$ & $\begin{array}{l}\text { Handling logistics operations such as transportation, } \\
\text { warehousing and inventories to reduce greenhouse } \\
\text { gas emissions }\end{array}$ & {$[12,48,55]$} \\
\hline & $\begin{array}{l}\text { Green HRM and } \\
\text { Green } \\
\text { transformational } \\
\text { leadership }\end{array}$ & $\begin{array}{l}\text { Policies, practices, and systems that stimulate a green behavior } \\
\text { of a company's employees in order to create an environmentally } \\
\text { sensitive, resource efficient and socially responsible workplace } \\
\text { and overall organization }\end{array}$ & [56-58] \\
\hline
\end{tabular}


Table 1. Cont.

\begin{tabular}{|c|c|c|c|}
\hline Criteria & Sub-Criteria & Description & $\begin{array}{l}\text { Some of the } \\
\text { References }\end{array}$ \\
\hline & $\begin{array}{l}\text { Environmental } \\
\text { management system }\end{array}$ & $\begin{array}{l}\text { To systematically ensure that commitment to environmental } \\
\text { protection improvement exists in the business organizations } \\
\text { towards environmental sustainability }\end{array}$ & {$[47,58-61]$} \\
\hline \multirow{5}{*}{ Social } & Health and safety & $\begin{array}{l}\text { Paying attention to the health and safety of the internal people } \\
\text { and also accident rates and noises being created }\end{array}$ & {$[13,48,62]$} \\
\hline & $\begin{array}{l}\text { Customization true } \\
\text { voice of stakeholders }\end{array}$ & $\begin{array}{l}\text { A systematic approach to understand the stakeholders' needs } \\
\text { and values to customize the services and products should be } \\
\text { tracked. Industry } 4.0 \text { enables supply chains to better define } \\
\text { customers' behaviors and needs. }\end{array}$ & {$[13,46,48]$} \\
\hline & $\begin{array}{l}\text { Support for charity } \\
\text { activities, arts and } \\
\text { cultural expression }\end{array}$ & $\begin{array}{l}\text { Culture protection ideas in product design and related services } \\
\text { to support art and culture expressions in addition to } \\
\text { participating in charity activities }\end{array}$ & {$[3,61,62]$} \\
\hline & $\begin{array}{l}\text { Human machine } \\
\text { Interaction } \\
\text { optimization }\end{array}$ & $\begin{array}{l}\text { Setting framework to mutual human and machine } \\
\text { communication, connections, collaboration and interfaces. This } \\
\text { is a prerequisite of Industry } 4 \text { functions }\end{array}$ & {$[44,46,59]$} \\
\hline & Decent work & $\begin{array}{l}\text { Employment that respects the fundamental rights of the human } \\
\text { person as well as the rights of workers in terms of conditions of } \\
\text { work safety and remuneration. Respect for the physical and } \\
\text { mental integrity of the worker in the exercise of } \\
\text { his/her employment }\end{array}$ & {$[55,57,63,64]$} \\
\hline
\end{tabular}

\section{Materials and Methods}

Due to the aim mentioned before, criteria in Table 1 are presented to 9 experts that have at least 3 years' experience of management in FMCG organizations that characteristics of their products, deterioration for instance, require especial expertise of 3PLs and increase the need of planning. Two other experts that have cooperated are university professors, from academic disciplines familiar with the knowledge of recent developments in this area.

First of all, the network of DEA technique (Figure 1) that is going to be developed after this, should be finalized. Nodes and inputs and outputs of each node of the DEA network (Figure 1) are determined by asking experts' opinions about the criteria in Table 1. Since literature review and experts' opinions conspicuously show that optimization, costeffective, and time-effective management are seriously important in the circular economy and Industry 4 logic, shaping an effective framework for sustainable supply chain management adoption would not be possible, unless coordination and cooperation among supply chain members happen in a way that innovative technologies, which are basics of Industry 4, could be implemented. This also brings about suitable principles of data management to cope with big data and enhances supply chain's resilience. So, management commitment to shape the supply chain, based upon Industry 4 principles, is considered as an input of "Governance" node in the network of DEA in this study by consulting experts. Management commitment and goal seeking makes the whole supply chain to unanimously consume needed time and effort in the path towards sustainability in Industry 4 era [21]. Besides, financial achievement is always an important measure for the success of for-profit supply chains. That is why capital consumed and revenue per year is considered as another input and, respectively, output of "Governance" node, respectively, in Figure 1. Another pillar of sustainability is environment and that is why this is the second node of the DEA network in current study. It is obvious that if 3PL service provider as a key member of supply chain wants to have a successful environmental performance, it should have a determined environmental vision, tracking the goals systematically $[14,64]$. These goals are set considering the criteria mentioned in the environment sector of the Table 1. So, based on the characteristics and comprehensiveness of 3PL service provider' environmental management system (EMS), it is expected that 3PL have more favorable 
environmental performance considering criteria in Table 1, which is about waste disposal, reduction in emissions, taking back recyclable goods to the manufacturers or other parts of the supply chain, etc. These characteristics are the ones that are under attention in circular economy principles.

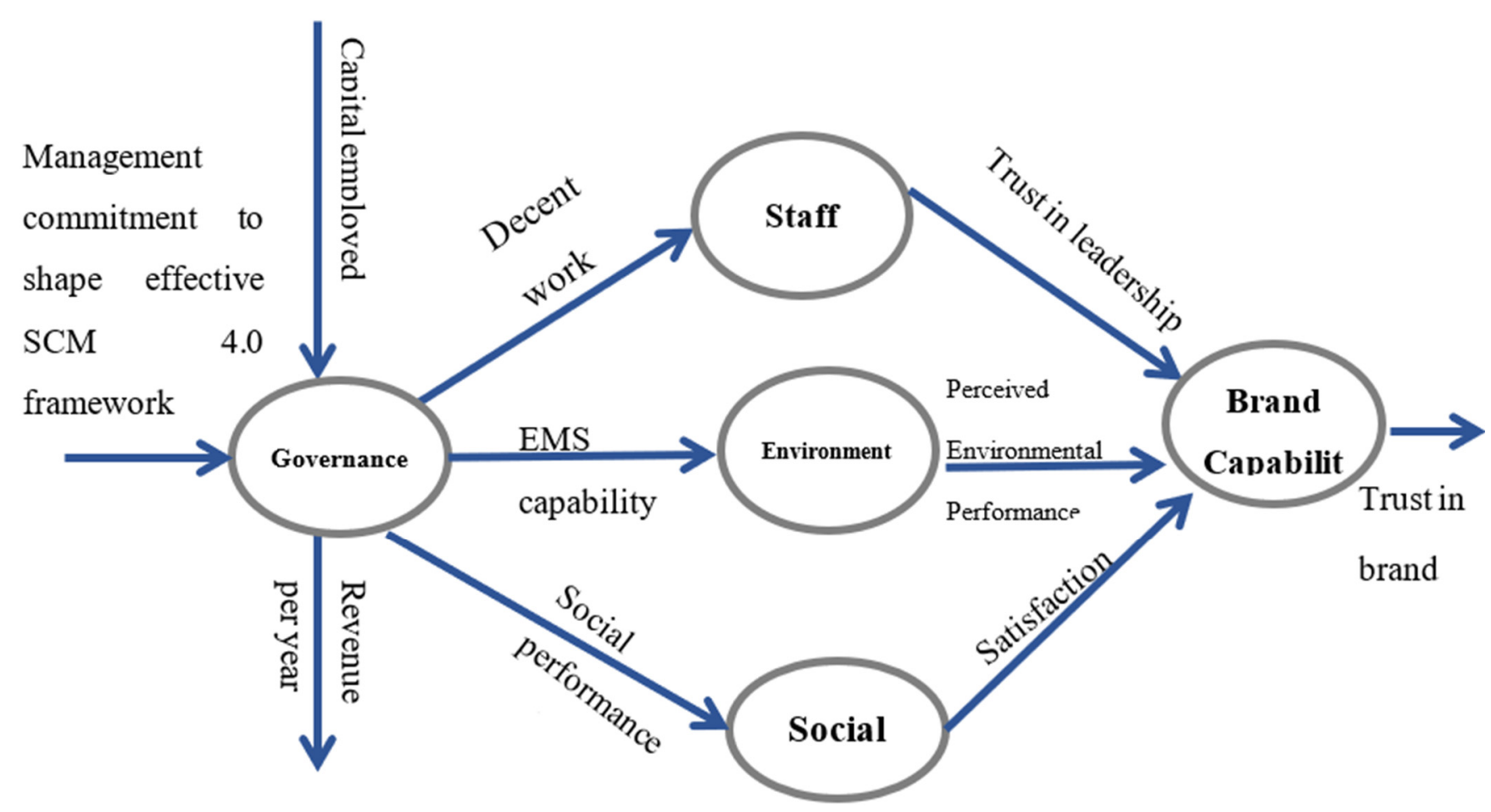

Figure 1. Current study DEA network.

Since interaction of human resources and machines has gained more attention in Industry 4 , setting a plan to enhance employees' skill and determination of compensation system is essential. For this reason, the "Staff" node is considered separately from the "Social" node that deals with other stakeholders of the supply chain. In this way, it becomes possible to determine the level of the employees' trust to the management capability to create decent work conditions in the path of change towards supply chain management 4.0 principles. The last node is "Brand Capability" which aimed to see the behavior of the 3PL compared with other stakeholders and the quality of actions to create shared value. Social criteria mentioned in Table 1 are used to design related questionnaires as mentioned in Table 2.

In the current study, weight of each node is determined based on the expert's opinions. Weights are close to together. However, it is clear that everything begins with a managers vision and their priorities sets the basis of the governance system. That is why the weight of "Governance" node in this study is 0.3 while the 3 other nodes of "social", "environment" and "staff" receive the same weights of 0.2 and, at last, the node called "brand capability" gains weight of 0.1 not because it is less important, but because if the procedures related to other nodes are taken smartly, brand will be subconsciously credited.

Table 2 depicts the nature of each component of the DEA network and shows how related data will be gathered. The decent work questionnaire developed by Ferraro et al. (2018) [65] is used to measure decent work. While trust of the employees to the leadership which constitutes the governance system of the organization is measured by referring to Nazmul Islam et al. (2020) [66] study, and Kähkönen et al. (2021) [67] study to see a transformational leadership concept while adjusting questionnaire. Since, social systems pay more attention to preserving the environment and also creation of shared values more than before, governance styles are going through transformational leadership. To 
gain information about the environment management system, framework proposed in Evangelista et al. (2018) [47] study constitutes the basis of questions asked from related managers of 3PLs in current study.

Table 2. Characterization of components.

\begin{tabular}{|c|c|c|c|}
\hline & Type & Nature & Value Estimation \\
\hline Management commitment & Input & Fuzzy & Senior managers opinions by the aid of questionnaire \\
\hline Capital employed & Input & Crisp & \multirow{2}{*}{ Official documents } \\
\hline Revenue per year & Output & Crisp & \\
\hline Decent work & Link & Fuzzy & \multirow{2}{*}{$\begin{array}{l}\text { Getting employees' opinions by the aid of } \\
\text { questionnaire }\end{array}$} \\
\hline Employee trust in leadership & Link & Fuzzy & \\
\hline EMS (Environmental Management System) & Link & Fuzzy & Consulting responsible managers \\
\hline Environmental performance & Link & Fuzzy & \multirow{3}{*}{$\begin{array}{l}\text { Getting stakeholders opinions by the aid of } \\
\text { questionnaire (Random sampling) }\end{array}$} \\
\hline Social performance quality & Link & Fuzzy & \\
\hline Satisfaction & Link & Fuzzy & \\
\hline Trust in brand & Output & Fuzzy & \\
\hline
\end{tabular}

A total of 17 3PLs are chosen to be investigated in this study. These 3PLs are the ones that cares about their brands images and sets visions for the better governance. All of them are capable of providing reverse logistics services and care about becoming environment friend while developing career path for their employees. "Isatis Rah Pars International Transportation Company" is among these 17 3PLs that are chosen to be studied. However, the names of these 3PLs service providers are abbreviated based on their management discretions.

Scholars adopted fuzzy approach to explicit uncertainty in information in different studies. As a result, fuzzy DEA models were developed [60,62,68,69]. However, criticisms have always been announced that the membership function of Type- 1 fuzzy sets does not contain any uncertainty. This is despite the fact that the fuzzy concept has the connotation of lots of uncertainty. The concept of Type-2 fuzzy sets is initially introduced by Zadeh [70] and is an extension of the concept of Type- 1 fuzzy set. Type- 2 fuzzy sets consider more uncertainty in comparison with general Type-1 fuzzy sets through application of general Type-1 fuzzy numbers in defining its membership function. Albeit, dealing with type-2 fuzzy sets calculations is complicated and interval type- 2 fuzzy sets could be more fruitful in this regard. Interval type-2 fuzzy numbers demonstrate the uncertainty of membership function by using interval value as Equation (1) [71]. The application of interval type-2 fuzzy number is not complicated and can keep uncertainty through the steps of analysis. The laws of calculations in interval type-2 fuzzy sets are not far from of laws of general type-1 fuzzy sets. A crisp number (like C) will simply turn into interval type-2 fuzzy number $(c, c, c, c ; 1,1)(c, c, c, c ; 0.9,0.9)$ [72]. Saying so, the value of each fuzzy variable of this study is determined by application of interval type-2 fuzzy numbers considering Equations (3) and (4) and the scale shown in Table 3.

$$
\begin{gathered}
A=\left(A^{U}, A^{L}\right)=\left(a_{1}^{U}, a_{2}^{U}, a_{3}^{U}, a_{4}^{U} ; H_{1}\left(A^{U}\right), H_{2}\left(A^{U}\right)\right),\left(a_{1}^{L}, a_{2}^{L}, a_{3}^{L}, a_{4}^{L} ; H_{1}\left(A^{L}\right), H_{2}\left(A^{L}\right)\right) \\
\frac{1}{k}(A)=\left(\frac{1}{k} a_{1}^{U}, \frac{1}{k} a_{2}^{U}, \frac{1}{k} a_{3}^{U}, \frac{1}{k} a_{4}^{U} ; H_{1}\left(A^{U}\right), H_{2}\left(A^{U}\right)\right),\left(\frac{1}{k} a_{1}^{L}, \frac{1}{k} a_{2}^{L}, \frac{1}{k} a_{3}^{L}, \frac{1}{k} a_{4}^{L} ; H_{1}\left(A^{L}\right), H_{2}\left(A^{L}\right)\right) \\
M_{*}(\tilde{A})=\frac{1}{6}\left(a_{5}^{U}+2 a_{6}^{U}\right) h_{1}^{U}+\frac{1}{6}\left(a_{1}^{L}+2 a_{2}^{L}\right) h_{1}^{L} \\
M^{*}(\tilde{A})=\frac{1}{6}\left(a_{8}^{U}+2 a_{7}^{U}\right) h_{2}^{U}+\frac{1}{6}\left(a_{4}^{L}+2 a_{3}^{L}\right) h_{2}^{L}
\end{gathered}
$$


Table 3. Scale to gather opinions.

\begin{tabular}{ll}
\hline Linguistic Variables & The Related Interval Type-2 Fuzzy Number \\
\hline Strongly agree & $(0.8,0.9,0.9,1: 1,1)(0.85,0.9,0.9,0.95: 0.9,0.9)$ \\
Agree & $(0.6,0.7,0.7,0.8: 1,1)(0.65,0.7,0.7,0.75: 0.9,0.9)$ \\
Undecided & $(0.4,0.5,0.5,0.6: 1,1)(0.45,0.5,0.5,0.55: 0.9,0.9)$ \\
Disagree & $(0.2,0.3,0.3,0.4: 1,1)(0.25,0.3,0.3,0.35: 0.9,0.9)$ \\
Strongly Disagree & $(0,0.1,0.1,0.1: 1,1)(0,0.1,0.1,0.05: 0.9,0.9)$ \\
\hline
\end{tabular}

The Extension of Interval Type-2 Fuzzy Network SBM DEA to Measure Efficiency and Super-efficiency

Charnes et al. [73] developed the initial DEA approached introduced by Farrell's model [74] considering multiple inputs and multiple outputs. After that, Banker et al. (1984) [75] introduced BCC model that deals with variable returns to scale (VRS) since Charnes et al. model deals with constant returns to scale [76]. However, such DEA models do not consider the interactions among the intermediate activities and that shaped the need to develop network DEA. Slacks-based measure network DEA model is one of the network DEA approaches that shows distance of each DMU from the best measure $[77,78]$. For determination of the efficiency of DMU, the conventional SBM-DEA model is done with Equations (5)-(8).

$$
\begin{gathered}
\min \rho_{o}=\frac{1-\frac{1}{k} \sum_{j=1}^{k} \frac{s_{j}^{-}}{x_{o}}}{1+\frac{1}{m} \sum_{n=1}^{m} \frac{s_{n}^{+}}{y_{o}}} \\
\text { s.t. } \quad \sum_{i=1}^{r} \lambda_{i} x_{i j}+s_{j}^{-}=x_{o} \quad j=1, \ldots, k \\
\sum_{i=1}^{r} \lambda_{i} y_{i n}-s_{n}^{+}=y_{o} \quad n=1, \ldots, m \\
\lambda_{i}, s_{j}^{-}, s_{n}^{+} \geq 0
\end{gathered}
$$

The performance should be described through a network of different aspects, and network DEA must be undertaken. The slack-based management network DEA (SBMNDEA) model determines the values of slack variables and assumes non-proportional change in the value of components [57]. To investigate the efficiency of each node in the network, intermediate activities are considered once as an output of a previous node, and once again as the input of the next node. Besides, equation $\sum_{j=1}^{n_{D M U s}} \lambda_{q j}=1$ helps the model to consider the variable return to scale (VRS) see model with Equations (9)-(16), $w^{q}$ is the weight of $q$ th node.

$$
\rho_{0}=\min \frac{\left[\sum_{k=1}^{q} w^{q}\left[1-\frac{1}{n_{\text {outputs }}+n_{\text {links-as-output }}}\left(\sum_{i=1}^{n_{\text {outputs }}} \frac{s_{i}^{k-}}{y_{o}^{k}}+\sum_{i=1}^{n_{\text {output.links }}} \frac{s_{i}^{(k, h) \text { output }}}{z_{o}^{(k, h)}}\right)\right]\right]}{\left[\sum_{k=1}^{q} w^{q}\left[1+\frac{1}{n_{\text {outputs }}+n_{\text {links-as-output }}}\left(\sum_{i=1}^{n_{\text {outputs }}} \frac{s_{i}^{k+}}{y_{o}^{k}}+\sum_{i=1}^{n_{\text {output.links }}} \frac{s_{i}^{(k, h) \text { output }}}{z_{o}^{(k, h)}}\right)\right]\right]}
$$

St:

$$
\begin{gathered}
\sum_{j=1}^{n_{D M U}} x_{j}{ }^{k} \lambda_{q j}+s_{q k}^{t-\text { input }}=x_{O} \quad q=1, \ldots, n_{\text {nodes }} \quad k=1, \ldots n_{\text {inputs }} \quad \text { Input } \\
\sum_{j=1}^{n_{D M U}} y_{j}{ }^{k} \lambda_{q j}-s_{q m}^{t-\text { output }}=y_{O} \quad q=1, \ldots, n_{\text {node }} s \quad m=1, \ldots n_{\text {outputs }} \quad \text { Outputs }
\end{gathered}
$$$$
\sum_{j=1}^{n_{\mathrm{DMU}}} z_{\text {linkj }}{ }^{(k, h)} \lambda_{q j}+s_{q r}^{(k, h) \text { input }}=z_{O}^{(k, h)} \quad q=1, \ldots, n_{\text {nodes }} \quad r=1, \ldots n_{\text {links }} \quad \text { link as input to node } h
$$ 


$$
\begin{gathered}
\sum_{j=1}^{n_{D M U}} z_{\text {link }}{ }^{(k, h)} \lambda_{q j}-s_{q r}^{(k, h) \text { output }}=z_{O}^{(k, h)} \quad q=1, \ldots, n_{\text {nodes }} \quad r=1, \ldots n_{\text {links }} \quad \text { link as output of node } k \\
\sum_{j=1}^{n_{D M U}} z_{\text {Linkj }}{ }^{(k, h)(\text { output })} \lambda_{q j}=\sum_{j=1}^{n_{D M U}} z_{\text {Linkj }}{ }^{(k, h)(\text { input })} \lambda_{q j} \quad \forall D M U \quad \text { preserving continuity condition of links } \\
\sum_{j=1}^{n_{D M U s}} \lambda_{q j}=1 \quad \forall q \\
\forall s, \lambda \geq 0
\end{gathered}
$$

This point is appropriate in that some of the input values are in a fuzzy nature and the determination of the exact value is not possible. Efficiency of the of the 3PLs' performances could become close, so it is better to distinguish efficient DMUs from each other by developing model in a way to measure super-efficiency scores too. One-stage model to simultaneously measure the efficiency of the inefficient DMUs and super-efficiency scores of the efficient DMUs is developed as Model 3 based on the study of [79] and can be seen in model with Equations (17)-(38).

$$
\rho_{O}=\min \left[\begin{array}{c}
(1-\alpha) \sum_{k=1}^{q} w^{q}\left[t_{1}-\frac{1}{n_{\text {inputs }}+n_{\text {links-as-input }}}\left(\sum_{i=1}^{n_{\text {inputs }}} \frac{s_{i}^{k-}}{x_{O}^{k}}+\sum_{i=1}^{n_{\text {input.links }}} \frac{s_{i}^{(k, h) \text { input }}}{z_{O}^{(k, h)}}\right)\right] \\
\alpha \sum_{k=1}^{q} w^{q}\left[\frac{1}{n_{\text {inputs }}+n_{\text {links }- \text { as -input }}}\left(\sum_{i=1}^{n_{\text {inputs }}} \frac{\tilde{x}_{i}}{x_{i o}}+\sum_{i=1}^{n_{\text {input.links }}} \frac{\tilde{z}_{i}}{z_{O}^{(k, h)}}\right)\right]
\end{array}\right]
$$

St:

$$
\begin{gathered}
\frac{1}{n_{\text {inputs }}+n_{\text {links-as-input }}}\left(\sum_{i=1}^{n_{\text {inputs }}} \frac{\tilde{x}_{i}}{x_{\text {io }}}+\sum_{i=1}^{n_{\text {input.links }}} \frac{\tilde{z}_{i}}{z_{O}^{(k, h)}}\right)-1 \leq \alpha \bar{M} \\
\alpha \in\{0 ; 1\}
\end{gathered}
$$

$$
\sum_{k=1}^{q} w^{q}\left[1+\frac{1}{n_{\text {outputs }}+n_{\text {links-as-output }}}\left(\sum_{i=1}^{n_{\text {outputs }}} \frac{s_{i}^{k+}}{y_{0}^{k}}+\sum_{i=1}^{n_{\text {output.links }}} \frac{s_{i}^{(k, h) \text { output }}}{z_{0}^{(k, h)}}\right)\right]+t_{1}=1
$$

$\sum_{j=1}^{n_{D M U}} \lambda_{1 q j} x_{j}^{k}+s_{q k}^{t-\text { input }}=x_{o} t_{1} \quad q=1, \ldots, n_{\text {nodes }} k=1, \ldots, n_{\text {inputs }}$ Inputs

$$
\sum_{j=1}^{n D M U} \lambda_{1 q j} y_{j}^{k}-s_{q m}^{t-o u t p u t}=y_{o} t_{1} q=1, \ldots, n_{\text {nodes }} m=1, \ldots, n_{\text {outputs }} \text { Outputs }
$$

$\sum_{j=1}^{n_{D M U}} \lambda_{1 q j} z_{\text {linkj }}^{(k, h)}+s_{q r}^{(k, h) \text { input }}=z_{o}^{(k, h)} t_{1} \quad q=1, \ldots, n_{\text {nodes }} \quad r=1, \ldots, n_{\text {links }}$ link as input to node $h$

$\sum_{j=1}^{n_{D M U}} \lambda_{1 q j} z_{\text {linkj }}^{(k, h)}-s_{q r}^{(k, h) o u t p u t}=z_{o}^{(k, h)} t_{1} \quad q=1, \ldots, n_{\text {nodes }} \quad r=1, \ldots, n_{\text {links }}$ link as output of node $k$

$\sum_{j=1}^{n_{D M U}} \lambda_{1 q j} z_{\text {linkj }}^{(k, h) \text { output }}=\sum_{j=1}^{n_{D M U}} \lambda_{1 q j} z_{\text {linkj }}^{(k, h) \text { input }} \forall D M U$ preserving continuity condition of links

$$
\sum_{j=1}^{n_{D M U s}} \lambda_{1 q j}=1 \quad \forall q
$$

$$
\begin{aligned}
1= & \sum_{k=1}^{q} w^{q}\left[\frac{1}{n_{\text {inputs }}+n_{\text {links-as-output }}}\left(\sum_{i=1}^{n_{\text {outputs }}} \frac{\tilde{y}_{i}}{y_{\text {io }}}+\sum_{i=1}^{n_{\text {output.links }}} \frac{\tilde{z}_{i}}{z_{O}^{(k, h)}}\right)\right] \\
& \sum_{j=1 ; j \neq 0}^{n_{D M U}} \lambda_{2 q j} x_{j}^{k} \leq \tilde{x}_{k} \quad q=1, \ldots, n_{\text {nodes }} k=1, \ldots, n_{\text {inputs }} \text { Inputs } \\
& \sum_{j=1 ; j \neq 0}^{n D M U} \lambda_{2 q j} y_{j}^{k} \geq \tilde{y}_{m} q=1, \ldots, n_{\text {nodes }} m=1, \ldots, n_{\text {outputs }} \text { Outputs }
\end{aligned}
$$

$\sum_{j=1 ; j \neq 0}^{n_{D M U}} \lambda_{2 q j} z_{\text {linkj }}^{(k, h)} \leq \tilde{z}_{r}^{(k, h)} \quad q=1, \ldots, n_{\text {nodes }} \quad r=1, \ldots, n_{\text {links }}$ link as input to node $h$ 


$$
\begin{gathered}
\sum_{j=1 ; j \neq 0}^{n_{D M U}} \lambda_{2 q j} z_{\text {linkj }}^{(k, h)} \geq \tilde{z}_{r}^{(k, h)} t_{1} q=1, \ldots, n_{\text {nodes }} \quad r=1, \ldots, n_{\text {links }} \text { link as output of node } k \\
\tilde{x}_{k} \geq t_{2} x_{k o} k=1, \ldots, n_{\text {inputs }} \\
\tilde{z}_{r}^{(k, h)} \geq t_{2} \tilde{z}_{r o}^{(k, h)} r=1, \ldots, n_{\text {links }} \\
0 \leq \tilde{y}_{m} \leq t_{2} y_{m o} m=1, \ldots, n_{\text {outputs }} \\
0 \leq \tilde{z}_{r}^{(k, h)} \leq t_{2} \tilde{z}_{r o}^{(k, h)} r=1, \ldots, n_{\text {links }} \\
\sum_{j=1}^{n_{D M U s}} \lambda_{2 q j}=1 \quad \forall q \\
t_{1}, t_{2}>0 \\
\forall s, \lambda_{1}, \lambda_{2} \geq 0
\end{gathered}
$$

$\bar{M}$ is a big positive number such as 10,$000 ; \lambda_{1 j}$ and $\lambda_{2 j}$, respectively, represent the non-negative vectors of the SBM model and the super SBM model; and $t_{1}$ and $t_{2}$ are two auxiliary variables for linearization. The objective function measures the efficiency score of an inefficient DMU $\left(\sum_{k=1}^{q} w^{q}\left[t_{1}-\frac{1}{n_{\text {inputs }}+n_{\text {links-as-input }}}\left(\sum_{i=1}^{n_{\text {inputs }}} \frac{s_{i}^{k-}}{x_{O}^{k}}+\sum_{i=1}^{n_{\text {input.links }}} \frac{s_{i}^{(k, h) \text { input }}}{z_{O}^{(k, h)}}\right)\right]\right)$ or super-efficiency score of an efficient DMU $\left(\sum_{k=1}^{q} w^{q}\left[\frac{1}{n_{\text {inputs }}+n_{\text {links }-a s-i n p u t}}\left(\sum_{i=1}^{n_{\text {inputs }}} \frac{\tilde{x}_{i}}{x_{i o}}+\right.\right.\right.$ $\left.\left.\sum_{i=1}^{n_{\text {input.links }}} \frac{\tilde{z}_{i}}{z_{O}^{(k, h)}}\right)\right]$ ).

Binary variable $\alpha \in\{0,1\}$ switches between the measure of efficiency based on the SBM model or the super SBM model. If $\alpha=1$, then the super SBM model is applied to compute the super-efficiency score of DMUO. If $\alpha=0$, then the SBM model is used to determine the efficiency score of DMUO. Equations (18) and (19) control switching between the SBM model and the super SBM model. Equations (21)-(26) are related to the linearized SBM model, while the constraints of the linearized super SBM model are Equations (27)-(36).

The developed model produces interval values of efficiency for each DMU of 3PLs. To finalize the rankings, the upper $(\bar{E})$ and lower $(\underline{E})$ limits of the efficiencies could be undertaken to compare efficiency level of the 2 DMUs (Equation (39)). The matrix of possibility degrees of preferences about DMUs as Equation (40) shows possibility degrees of preferences of a DMU against other ones in each row. This matrix surely contains a row with degrees of equal or more than 0.5 value. The related DMU gets the first rank in this way. Other DMUs are ranked after elimination of row and column of the mentioned DMU one by one after that [79].

$$
\begin{gathered}
P\left(E_{2} \succ E_{1}\right)=\frac{\max \left(0,\left(\left(\overline{E_{2}}-\underline{E_{2}}\right)+\left(\overline{E_{1}}-\underline{E_{1}}\right)-\max \left(0,\left(\overline{E_{1}}-\underline{E_{2}}\right)\right)\right.\right.}{\left(\overline{E_{2}}-\underline{E_{2}}\right)+\left(\overline{E_{1}}-\underline{E_{1}}\right)} \\
P=\left(\begin{array}{ccc}
\left(E_{1} \succ E_{1}\right) & \ldots & \left(E_{1} \succ E_{n}\right) \\
\left(E_{2} \succ E_{1}\right) & \ldots & \left(E_{2} \succ E_{n}\right) \\
\cdot & \cdot & \cdot \\
\cdot & \cdot & \cdot \\
\left(E_{n} \succ E_{1}\right) & \ldots & \left(E_{n} \succ E_{n}\right)
\end{array}\right)
\end{gathered}
$$

\section{Results}

Based on the characteristics of components of DEA network mentioned in Table 2, values are gathered by the use of a questionnaire tool or official documents related to 17 most famous 3PLs service providers in food and health industry in Iran. The need of the FMCG industry to follow world's taste in food and health industry put some requirements on the management of the supply chain which logistics play an important role in it. Management of these 3PLs service providers are familiar with sustainable supply 
chain concept and circular principles. This enhances competition among 3PLs making them pay more attention to global trends.

Considering the extension of Interval type-2 fuzzy network one step SBM DEA in Section 3, performance efficiencies of these 3PLs are depicted in Table 4.

Table 4. Efficiencies of 17 3PLs service providers and their ranks considering components in Figure 1.

\begin{tabular}{|c|c|c|c|c|c|c|c|c|c|c|c|c|c|}
\hline \multicolumn{14}{|c|}{ Efficiency Value } \\
\hline \multicolumn{2}{|c|}{ 3PLs } & \multicolumn{2}{|l|}{ Total } & \multicolumn{2}{|c|}{ Governance Node } & \multicolumn{2}{|c|}{ Staff Node } & \multicolumn{2}{|c|}{ Environment Node } & \multicolumn{2}{|c|}{ Social Node } & \multicolumn{2}{|c|}{ Brand Capability Node } \\
\hline 1 & TOR & {$[0.43,0.45]$} & 15 & {$[0.4,0.59]$} & 8 & {$[0.81,1]$} & 4 & {$[0.37,0.45]$} & 15 & {$[0.3,0.46]$} & 15 & {$[0.28,0.31]$} & 16 \\
\hline 2 & KHA & {$[0.43,0.57]$} & 8 & {$[0.83,1]$} & 3 & {$[0.16,0.61]$} & 13 & {$[0.7,1]$} & 5 & {$[0.5,0.72]$} & 9 & {$[0.66,0.79]$} & 4 \\
\hline 3 & ZANJ & {$[0.51,0.66]$} & 3 & {$[0.45,0.47]$} & 9 & {$[0.44,1]$} & 6 & {$[0.68,1]$} & 7 & {$[0.98,1.3]$} & 1 & {$[0.65,0.79]$} & 5 \\
\hline 4 & KHF & {$[0.46,0.48]$} & 13 & {$[0.24,0.26]$} & 15 & {$[0.3,0.32]$} & 15 & {$[0.33,0.4]$} & 16 & {$[0.51,0.6]$} & 11 & {$[0.51,0.62]$} & 12 \\
\hline 5 & KAL & {$[0.46,0.53]$} & 9 & {$[0.61,0.72]$} & 6 & {$[0.45,0.48]$} & 8 & {$[0.94,1]$} & 2 & {$[0.25,0.3]$} & 17 & {$[0.33,0.39]$} & 15 \\
\hline 6 & PRES & {$[0.42,0.49]$} & 14 & {$[0.26,0.37]$} & 14 & {$[0.38,0.42]$} & 12 & {$[0.58,0.67]$} & 9 & {$[0.66,0.79]$} & 5 & {$[0.36,0.51]$} & 14 \\
\hline 7 & TEH & {$[0.54,0.66]$} & 2 & {$[0.98,1.2]$} & 2 & {$[1,1.1]$} & 1 & {$[0.84,1]$} & 4 & {$[0.75,1]$} & 2 & {$[0.89,1.22]$} & 1 \\
\hline 8 & SHAR & {$[0.46,0.48]$} & 13 & {$[0.31,0.38]$} & 12 & {$[0.41,0.51]$} & 9 & {$[0.47,0.59]$} & 12 & {$[0.64,0.71]$} & 6 & {$[0.26,0.31]$} & 16 \\
\hline 9 & DAR & {$[0.49,0.59]$} & 5 & {$[0.27,0.64]$} & 10 & {$[0.35,1]$} & 7 & {$[0.45,1]$} & 8 & {$[0.61,1]$} & 4 & {$[0.57,0.59]$} & 11 \\
\hline 10 & PARS & {$[0.47,0.48]$} & 12 & {$[0.3,0.33]$} & 14 & {$[0.27,0.33]$} & 16 & {$[0.48,0.57]$} & 13 & {$[0.61,0.63]$} & 7 & {$[0.53,0.64]$} & 10 \\
\hline 11 & SADI & {$[0.48,0.54]$} & 6 & {$[0.43,0.46]$} & 11 & {$[0.33,0.51]$} & 11 & {$[0.84,0.85]$} & 6 & {$[0.42,0.77]$} & 10 & {$[0.81,0.85]$} & 3 \\
\hline 12 & ISF & {$[0.47,0.49]$} & 11 & {$[0.45,0.64]$} & 7 & {$[0.3,0.36]$} & 14 & {$[0.46,0.52]$} & 14 & {$[0.3,0.41]$} & 16 & {$[0.51,0.6]$} & 13 \\
\hline 13 & ISA & {$[0.54,0.68]$} & 1 & {$[0.93,1.3]$} & 1 & {$[0.51,1]$} & 5 & {$[0.85,1.16]$} & 1 & {$[0.7,1]$} & 3 & {$[0.66,0.76]$} & 6 \\
\hline 14 & IRAN & {$[0.48,0.49]$} & 10 & {$[0.22,0.45]$} & 13 & {$[0.2,0.21]$} & 17 & {$[0.32,0.37]$} & 17 & {$[0.43,0.51]$} & 13 & {$[0.62,0.64]$} & 8 \\
\hline 15 & ABAD & {$[0.48,0.53]$} & 7 & {$[0.24,0.26]$} & 15 & {$[0.33,0.52]$} & 10 & {$[0.38,0.72]$} & 10 & {$[0.61,0.63]$} & 7 & {$[0.63,0.64]$} & 7 \\
\hline 16 & BALO & {$[0.46,0.5]$} & 11 & {$[0.74,1]$} & 5 & {$[0.94,1]$} & 3 & {$[0.46,0.64]$} & 10 & {$[0.36,0.54]$} & 14 & {$[0.58,0.66]$} & 9 \\
\hline 17 & BARES & {$[0.52,0.58]$} & 4 & {$[0.77,1]$} & 4 & {$[0.94,1.05]$} & 2 & {$[0.94,1]$} & 2 & {$[0.44,0.61]$} & 12 & {$[0.7,1]$} & 2 \\
\hline
\end{tabular}

"ISA", "THE", and "ZANJ" are the 3 most efficient DMUs. Other 3PLs could benchmark the points and the path taken by these efficient ones.

\section{Discussion}

As is obvious by talking to managers, economic turmoil is overwhelming when managing organizations in many countries, and they could not pay attention to other matters more than an obligatory amount. This is the most impressive reason not to see a systematic approach in social, environment, or even behaving with staff. However, stakeholders are gaining knowledge about sustainability importance and preserving the environment, and this oblige businesses to pay more attention to such principles. Moving towards the implementation of circular principles with environment management systems as a facilitator towards sustainability needs expertise. Inviting customers to bring back products at their end-of-life while gaining capabilities in lean production to reduce waste; the implementation of reverse logistics systems with suitable strategy in each part of the supply chain (retailer, whole seller, manufacturer, etc.) would not be fruitful, unless done homogeneously. That is why to become a true leader in this era with such complexities in each domain of social, the environment, and economics, an organization needs to shake up its business model and making it innovative. The product service system (PPS) is one of the innovative business models. This model is based on the idea that users just need the function the product provides. So, there is no necessity for them to buy the product. Businesses can just provide a service contract rather than selling the physical product [61].

Supply chains could reach the maximum level of performance in this regard, albeit, figuring out how to manage this integration through the supply chain, taking into account a suitable strategy and roadmap, requires delicate work. It should be determined who is responsible to gather managers of the supply chain to set goals and related strategies, and also measure the environment performance of the whole supply chain in specified time period. All of these need deep change that will not be realized unless all the employees through the supply chain become ready to be involved. This requires transformational leadership which means a new style of governance for many supply chains. Transformational leader proactively acts as a change agent, raises employees' awareness by enhancing their collective interests and qualifications, and helps them to achieve exceptional goals [66]. 
When leaders become justified about the importance of paying attention to social, the environment, and economics at the same time, and also get the capabilities of a transformational leader; and when all the supply chain members get aligned, now it is the time to set the new business model and a strategic measurement framework to monitor and evaluate the performance [59].

Another point that is worth taking into consideration is that to see which of the 5 nodes of "Governance", "Staff", "Environment", "Social", and "Brand capability" considered in the network are more important than the others. Analysis shows that in 4 3PL systems, "Governance" node is more efficient than other ones; in 3 3PL system, "Staff" node is more efficient than other ones; in 2 3PL system, "Environment" node is more efficient than other ones; in 5 3PL system, "Social" node is more efficient than the 4 other ones; and at last, in 4 3PL system, "Brand Capability" node is more efficient than the 4 other ones. A clear point is that investing in each first 4 nodes do not necessarily cause the 3PL's brand capablilities. Society should see the efforts of the PLs system providers. So, it is important that 3PLs find a good way to convey its message and show its efforts. In this way, people become aware of the supply chain's concerns and brand will gain more credits as such.

On a more proactive note, it should also be noted that the role of business in the society has gained an evolving approach and the shared value is the one that is mentioned after sustainability. While sustainability is the equilibrium between economy, society, and environment, the shared value is to seek integration between societal improvements into economic value creation. In this approach, social improvement should be considered in the business model and all of these are not independent of the circular supply chain strategies [6,7]. All the businesses should show that their supply chain is intended to become more sustainable day by day and create shared value in this way. Leading businesses in FMCG industry, such as Nestlé, regularly publish reports on their social and environmental functions and make them available to the public [80]. In this way, they let people around the world know that they care about people's quality of life, and also preserving the environment, along with their economic status and financial profitability. Responsible behavior of brands is more important than ever, especially in the FMCG industry, since their interaction with consumers is more frequent in comparison with other brands. Many consumers are willing to pay more for "sustainable brands" and they want brands to be responsible against society and environment. Sustainability is an emotive subject that can build or break a consumer's relationship with a brand.

It is notable that in 4 3PL systems, the "Governance" node is more efficient than other ones. However, it is clear that being efficient in the "Governance" node does not always lead to being efficient with all other nodes. The governance system is a driver to the performance of other nodes. Maybe managers are convinced that a sufficient budget should be consumed in order to improve work conditions or participate in social and environmental events, but if the action plans are not defined properly and the results of projects are not assessed, the effectiveness of the functions is not specified and the changes made will not be maintained in the long run. Everything will be forgotten after a while and brands will again get busy with economic challenges. In fact, projects should be defined and prioritized; achievements should be assessed; knowledge management should be considered to learn from experiences and use them in future opportunities; arrangements must be made to maintain the new behavioral system formed as a result of the implementation of projects and at last, brands' public relations managers should not be afraid of sharing the achievements with the society.

Whatever the strategies are, it should always be under attention that economic, society and environment issues should be considered simultaneously. There should be always a holistic approach. Selling goods online has its advantages for environment and society for instance, but if goods are sold through ecommerce system, there will be new issues to consider in various domain of business such as marketing. Even the packaging has to fulfil many roles, ranging from protection of the product to transferring a suitable brand image. Such packaging needs to be lightweight enough to minimize shipping costs, and 
also robust enough to survive the returns process if needed. It is good to be recyclable and also still needs to be attractive to the consumer's eye.

Since in just 2 3PL system, the "Environment" node is more efficient than other ones, it shows that Iranian 3PLs have a long way to go to transition into the circular economy models. A number of FMCG brands, such as Nestlé, Pepsi, Unilever, have embraced a circular economy model trying to dominate the obstacles against them to become truly sustainable. It is important since FMCG brands are driving the plastic pollution crisis. Even in most developed countries people are reliant on the plastic infused products and it is nearly impossible not to create plastic waste. Reverse logistic systems as a crucial tool to reduce waste amount need to be more efficient and integrated with supply chain management strategy. Leveraging reverse logistics in FMCG industry needs managing quality of circular goods along with responsibility and initiation by top management [81].

Supply chain resilience is another essential item to the success of firms. Transportation system of the supply chain should be also resilience and it is when it has the ability to absorb disruptive events and goes back to a level of performance equal to or even better than the pre-disruption level of service within a reasonable time period [33-35]. Robustness, redundancy, resourcefulness, and rapidity are four mentioned characteristics that could interpret the resilience capability of the transportation network. Robustness reflects the ability to resist a disruption effect without significant system degradation; Redundancy is the capability to which alternative routes and transportation modes can be used if first ones are damaged; Resources is related to the availability of what is needed to restore functionality; and Rapidity is the ability to get to the first level of performance in a timely manner. So, redundancy and resources can improve resilience, while robustness and rapidity are helpful achieving a resilient system [36].

\section{Conclusions}

The knowledge of sustainability has got attention more than before and new technologies, tools and principles, such as the ones that are created during the Industry 4 era or by the circular economy concept, try to pave the path towards sustainability. Although transportation has undeniable importance through the supply chain especially the supply chain of FMCG because of its unique characteristics, it is not fully adjusted with circular economy principles. Even in developed countries, reverse logistics contain challenges, let alone developing countries [55].

This study considers Industry 4 achievements and challenges, the principles of a circular economy in the environment management system, and their effects on the performance of 3PLs service providers that are aimed to professionally provide transportation services to the supply chains. Consideration of all of these important elements all together to evaluate the performance of 3PLs in developing counties is unprecedented and highlight the importance of current study. Besides, since 3PLs are in their beginning of the path and need to gain experience to improve their business model and make it compatible with other parts of the supply chain, it is essential to let them use the experience of the ones that has done their job better. Such benchmarking helps them to improve their brand capabilities while structuring to costs. An interval type-2 fuzzy DEA model is developed in this study to evaluate efficiency and also super-efficiency of 3PLs to provide the basis for benchmarking. Now, each 3PLs knows its position among others and could take the experience of others to eliminate its weakness. Results show that considering sustainability principles in the governance system does not essentially help the brand to become valid among stakeholders. There must be a way for them to feel the changes taken by the system. The other point goes to the matter that although economic situation is vulnerable nowadays, management cannot postpone paying attention to other elements of sustainability more than this and should set a business model to implement principles of sustainability simultaneously and homogeneously with other parts of the supply chain.

For the next study, it is suggested to investigate setting a strategic measurement framework to monitor and evaluate the sustainability performance of 3PLs and their 
alignment with other parts of the supply chain as a whole. Besides, it is good to develop a fuzzy type-2 network DEA model which is dynamic to become able to evaluate the performance of the 3PLs in different time scales. Such studies are fruitful to be done about the whole supply chains too.

Author Contributions: Conceptualization, M.P.; methodology; software; validation, and formal analysis, M.D.S. and M.P.; writing-original draft preparation, M.D.S., M.P., and A.V.; writingreview and editing; supervision, J.A. All authors have read and agreed to the published version of the manuscript.

Funding: This research received no external funding.

Institutional Review Board Statement: Not applicable.

Informed Consent Statement: Not applicable.

Data Availability Statement: Data sharing not applicable.

Conflicts of Interest: The authors declare no conflict of interest.

\section{References}

1. González-Sánchez, R.; Settembre-Blundo, D.; Ferrari, A.M.; García-Muiña, F.E. Main Dimensions in the Building of the Circular Supply Chain: A Literature Review. Sustainability 2020, 12, 2459. [CrossRef]

2. Akinade, O.O.; Oyedele, L.O. Integrating construction supply chains within a circular economy: An ANFIS-based waste analytics system (A-WAS). J. Clean. Prod. 2019, 229, 863-873. [CrossRef]

3. Salehi-Amiri, A.; Zahedi, A.; Akbapour, N.; Hajiaghaei-Keshteli, M. Designing a sustainable closed-loop supply chain network for walnut industry. Renew. Sust. Energ. Rev. 2021, 141, 1-20. [CrossRef]

4. Igl, J.; Kellner, F. Exploring greenhouse gas reduction opportunities for retailers in Fast Moving Consumer Goods distribution networks. Transp. Res. D Transp. Environ. 2017, 278, 296-313. [CrossRef]

5. Cowan, K.; Guzman, F. How CSR reputation, sustainability signals, and country-of-origin sustainability reputation contribute to corporate brand performance: An exploratory study. J. Bus. Res. 2020, 117, 683-693. [CrossRef]

6. Harfouche, A. ICT for an Inclusive World: Industry 4.0-Towards the Smart Enterprise; Springer: Berlin/Heidelberg, Germany, 2020; pp. 37-74. ISBN 3030342697.

7. Moktadir, M.A.; Dwivedi, A.; SultanaKhan, N.; KumarPaul, S.; AhmedKhan, S.; Ahmed, S.; Sultana, R. Analysis of risk factors in sustainable supply chain management in an emerging economy of leather industry. J. Clean. Prod. 2021, 283, 124641. [CrossRef]

8. Lu, S.; Zhu, L.; Wang, Y.; Xie, L.; Su, L. Integrated forward and reverse logistics network design for a hybrid assembly-recycling system under uncertain return and waste flows: A fuzzy multi-objective programming. J. Clean. Prod. 2020, 243. [CrossRef]

9. Kellner, F.; Lienland, B.; Utz, S. An a posteriori decision support methodology for solving the multi-criteria supplier selection problem. Eur. J. Oper. Res. 2019, 272, 505-522. [CrossRef]

10. Guarnieri, P.; Sobreiro, V.A.; Nagano, M.S.; Serrano, A.L.M. The challenge of selecting and evaluating third-party reverse logistics providers in a multi-criteria perspective: A Brazilian case. J. Clean. Prod. 2015, 96, 209-219. [CrossRef]

11. Hammes, G.; Souza, E.D.D.; Rodriguez, C.M.T.; Millan, R.H.R.; Herazo, J.C.M. Evaluation of the reverse logistics performance in civil construction. J. Clean. Prod. 2020, 248, 119212. [CrossRef]

12. Zarbakhshnia, N.; Soleimani, H.; Goh, M.; Razavi, S.S. A novel multi-objective model for green forward and reverse logistics network design. J. Clean. Prod. 2019, 208, 1304-1316. [CrossRef]

13. Zarbakhshnia, N.; Soleimani, H.; Ghaderi, H. Sustainable third-party reverse logistics provider evaluation and selection using fuzzy SWARA and developed fuzzy COPRAS in the presence of risk criteria. Appl. Soft Comput. 2018, 65, 307-319. [CrossRef]

14. Ali, A.; Chauhan, K.; Barakat, M.; Eid, A. The Role of Sustainability for Enhancing Third-Party Logistics Management Performance. J. Manag. Sustain. 2019, 9, 1925-4733. [CrossRef]

15. Kalantary, M.; Farzipoor Saen, R. Assessing sustainability of supply chains: An inverse network dynamic DEA model. Comput. Ind. Eng. 2019, 135, 1224-1238. [CrossRef]

16. Zhou, X.; Wang, Y.; Chai, J.; Wang, L.; Wang, S.; Lev, B. Sustainable supply chain evaluation: A dynamic double frontier network DEA model with interval type-2 fuzzy data. Inf. Sci. 2019, 504, 394-421. [CrossRef]

17. Rodrigues, L.C.; Martins, R.S.; Wanke, P.F.; Siegler, J. Efficiency of specialized 3PL providers in an emerging economy. Int. J. Prod. Econ. 2018, 205, 163-178. [CrossRef]

18. Qin, R.; Liu, Y.-K.; Liu, Z.-Q. Methods of critical value reduction for type-2 fuzzy variables and their applications. J. Comput. Appl. Math. 2011, 235, 1454-1481. [CrossRef]

19. Dossou, P.E. Impact of Sustainability on the supply chain 4.0 performance. Procedia Manuf. 2018, 17, 452-459. [CrossRef]

20. Pishdar, M.; Ghasemzadeh, F.; Antuchevičienè, J.; Saparauskas, J. Internet of Things and Its Challenges in Supply Chain Management: A Rough Strength-Relation Analysis Method. Ekon. Manag. 2018, 21, 208-222. [CrossRef] 
21. Yadav, G.; Luthra, S.; Jakhar, S.K.; Mangla, S.K.; Rai, D.P. A framework to overcome sustainable supply chain challenges through solution measures of Industry 4.0 and circular economy: An automotive case. J. Clean. Prod. 2020, 254, 120112. [CrossRef]

22. Ghadge, A.; Kara, M.E.; Moradlou, H.; Goswami, M. The impact of Industry 4.0 implementation on supply chains. J. Manuf. Technol. Manag. 2020, 31, 669-686. [CrossRef]

23. Bag, S.; Telukdarie, A.; Pretorius, J.H.C.; Gupta, S. Industry 4.0 and Supply Chain Sustainability: Framework and Future Research Directions. Bench. Inter. J. 2018, 1-41. [CrossRef]

24. Birkel, H.; Müller, J.M. Potentials of Industry 4.0 for supply chain management within the triple bottom line of sustainability-A systematic literature review. J. Clean. Prod. 2020, 289, 125612. [CrossRef]

25. Sharma, M.; Kamble, S.; Mani, V.; Sehrawat, R.; Belhadi, A.; Sharma, V. Industry 4.0 adoption for sustainability in multi-tier manufacturing supply chain in emerging economies. J. Clean. Prod. 2021, 281. [CrossRef]

26. Massaro, M.; Secinaro, S.; Mas, F.D.; Brescia, V.; Calandra, D. Industry 4.0 and circular economy: An exploratory analysis of academic and practitioners' perspectives. Bus. Strategy Environ. 2020, 30, 1213-1231. [CrossRef]

27. Kumar, P.; Singh, R.K.; Kumar, V. Managing supply chains for sustainable operations in the era of Industry 4.0 and circular economy: Analysis of barriers. Resour. Conserv. Recycl. 2021, 164, 1-12. [CrossRef]

28. Batarlienè, N.; Jarašūnienè, A. “3PL” Service Improvement Opportunities in Transport Companies. Procedia Eng. 2017, 187, 67-76. [CrossRef]

29. Wang, F.; Yang, X.; Zhuo, X.; Xiong, M. Joint logistics and financial services by a 3PL firm: Effects of risk preference and demand volatility. Transp. Res. E-Log. 2019, 130, 312-328. [CrossRef]

30. Vafaei, A.; Yaghoubi, S.; Tajik, J.; Barzinpour, F. Designing a sustainable multi-channel supply chain distribution network: A case study. J. Clean. Prod. 2020, 251, 119628. [CrossRef]

31. Yavas, V.; Ozkan-Ozen, Y.D. Logistics centers in the new industrial era: A proposed framework for logistics center 4.0. Transp. Res. E-Log. 2020, 135, 1-18. [CrossRef]

32. Adivar, B.; Hüseyinoğlu, I.O.Y.; Christopher, M.A. Quantitative performance management framework for assessing omnichannel retail supply chains. J. Retail. Consum. Serv. 2019, 48, 257-269. [CrossRef]

33. Liu, C.L.; Lee, M.Y. Integration, supply chain resilience, and service performance in third-party logistics providers. Int. J. Logist. Manag. 2018, 29, 5-21. [CrossRef]

34. Yang, Z.; Lun, V.; Lagoudis, L.N.; Lee, P.T.W. Container transportation: Resilience and sustainability. Transp. Res. D Transp. Environ. 2018, 61 Pt B, 420-422. [CrossRef]

35. Renne, J.; Wolshon, B.; Murray-Tuite, P.; Pande, A. Emergence of resilience as a framework for state Departments of Transportation (DOTs) in the United States. Transp. Res. D Transp. Environ. 2020, 82, 1-11. [CrossRef]

36. Leobons, C.M.; Campos, V.B.G.; Bandeira, R.A.M. Assessing Urban Transportation Systems Resilience: A Proposal of Indicators. Transp. Res. Procedia 2019, 37, 322-329. [CrossRef]

37. Bonilla, S.H.; Silva, H.R.O.; Silva, M.T.D.; Gonçalves, R.F.; Sacomano, J.B. Industry 4.0 and Sustainability Implications: A ScenarioBased Analysis of the Impacts and Challenges. Sustainability 2018, 10, 3740. [CrossRef]

38. Reis, J.Z.F.; Gonçalves, R.F. The Role of Internet of Services (IoS) on Industry 4.0 through the Service Oriented Architecture (SOA). In Proceedings of the IFIP WG 5.7 International Conference, APMS 2018, Seoul, Korea, 26-30 August 2018. [CrossRef]

39. Ghobakhloo, M. The future of manufacturing industry: A strategic roadmap toward Industry 4.0. The future of manufacturing industry: A strategic roadmap toward Industry 4.0. J. Manuf. Technol. Manag. 2018, 29, 910-936. [CrossRef]

40. Zameer, H.; Wang, Y.; Yasmeen, H. Reinforcing green competitive advantage through green production, creativity and green brand image: Implications for cleaner production in China. J. Clean. Prod. 2020, 247, 119119. [CrossRef]

41. Zaid, A.A.; Jaaron, A.A.M.; Bon, A.T. The impact of green human resource management and green supply chain management practices on sustainable performance: An empirical study. J. Clean. Prod. 2018, 204, 965-979. [CrossRef]

42. Singh, S.K.; Giudice, M.D.; Chierici, R.; Graziano, D. Green innovation and environmental performance: The role of green transformational leadership and green human resource management. Technol. Soc. Chang. 2021, 150, 1-12. [CrossRef]

43. Stock, T.; Obenaus, M.; Kunz, S.; Kohl, H. Industry 4.0 as enabler for a sustainable development: A qualitative assessment of its ecological and social potential. Process Saf. Environ. 2018, 118, 254-267. [CrossRef]

44. Sony, M.; Naik, S. Industry 4.0 integration with socio-technical systems theory: A systematic review and proposed theoretical model. Technol. Soc. 2020, 61, 1-45. [CrossRef]

45. Raj, A.; Dwivedi, G.; Sharma, A.; Sousa Jabbour, A.B.L.; Rajak, S. Barriers to the adoption of Industry 4.0 technologies in the manufacturing sector: An inter-country comparative perspective. Int. J. Prod. Econ. 2020, 224, 1-48. [CrossRef]

46. Beier, G.; Ullrich, A.; Niehoff, S.; Reißig, M.; Habich, M. Industry 4.0: How it is defined from a sociotechnical perspective and how much sustainability it includes-A literature review. J. Clean. Prod. 2020, 259, 1-13. [CrossRef]

47. Evangelista, P.; Santoro, L.; Thomas, A. Environmental Sustainability in Third-Party Logistics Service Providers: A Systematic Literature Review from 2000-2016. Sustainability 2018, 10, 1627. [CrossRef]

48. Mavi, N.K.; Mavi, R.K. Energy and environmental efficiency of OECD countries in the context of the circular economy: Common weight analysis for malmquist productivity index. J. Environ. Manag. 2019, 247, 651-661. [CrossRef]

49. Trappey, A.J.C.; Trappey, C.V.; Govindarajan, U.H.; Chuang, A.C.; Sun, J.J. A review of essential standards and patent landscapes for the Internet of Things: A key enabler for Industry 4.0. Adv. Eng. Inf. 2017, 33, 208-229. [CrossRef] 
50. Burns, T.; Cosgrove, J.; Doyle, F. A Review of Interoperability Standards for Industry 4.0. Procedia Manuf. 2019, 38, 646-653. [CrossRef]

51. Ozkan-Ozen, Y.D.; Kazancoglu, Y.; Kumar Mangla, S. Synchronized Barriers for Circular Supply Chains In Industry 3.5/Industry 4.0 Transition for Sustainable Resource Management. Resour. Conserv. Recycl. 2020, 161, 104986. [CrossRef]

52. Guerrero-Lorente, J.; Gabor, A.F.; Ponce-Cueto, E. Omnichannel logistics network design with integrated customer preference for deliveries and returns. Comput. Ind. Eng. 2020, 144, 106433. [CrossRef]

53. Rajesh, R.; Pugazhendhi, S.; Ganesh, K.; Muralidharan, C.; Sathiamoorthy, R. Influence of 3PL service offerings on client performance in India. Transp. Res. E-Log. 2011, 47, 149-165. [CrossRef]

54. Gu, Y.; Fu, X.; Liu, Z.; Xu, X.; Chen, A. Performance of transportation network under perturbations: Reliability, vulnerability, and resilience. Transp. Res. E-Log. 2020, 133, 101809. [CrossRef]

55. Barón, A.; Castro, R.D.; Giménez, G. Circular Economy Practices among Industrial EMAS-Registered SMEs in Spain. Sustainability 2020, 12, 9011. [CrossRef]

56. Hyejune, P.; Kim, Y.K. Proactive versus reactive apparel brands in sustainability: Influences on brand loyalty. J. Retail. Consum. Serv. 2016, 29, 114-122. [CrossRef]

57. Olfat, L.; Pishdar, M.; Ghasemzadeh, F. Type-2 Fuzzy Network Data Envelopment Analysis for FMCG Distributors' Performance Evaluation with Sustainability Approach. Int. J. Ind. Eng. Theory 2019, 26, 663-687.

58. Kumar, A.; Moktadir, M.D.A.; Rehman Khan, S.A.; Garza-Reyes, J.A.; Tyagi, M.; Kazançoğlu, Y. Behavioural factors on the adoption of sustainable supply chain practices. Resour. Conserv. Recycl. 2020, 158, 1-12. [CrossRef]

59. Franco, N.G.; Ludovico Almeida, N.F.; Flora Calili, R. A strategic measurement framework to monitor and evaluate circularity performance in organizations from a transition perspective. Sustain. Prod. Consum. 2021, 27, 1165-1182. [CrossRef]

60. Olfat, L.; Amiri, M.; Bamdad Soufi, J.; Pishdar, M. A Dynamic Network Efficiency Measurement of Airports Performance Considering Sustainable Development Concept: A Fuzzy Dynamic Network-DEA Approach. J. Air Transp. Manag. 2016, 57, 272-290. [CrossRef]

61. European Union. Moving towards a Circular Economy with EMAS. Available online: https://ec.europa.eu/environment/emas/ pdf/other/report_EMAS_Circular_Economy.pdf (accessed on 2 April 2021).

62. Olfat, L.; Pishdar, M. Interval Type-2 Fuzzy Dynamic Network Data Envelopment Analysis with Undesirable Outputs Considering Double Frontiers: An Application to Iran Airports' Sustainability Evaluation. Int. J. Ind. Eng. Theory 2017, 24, 635-662.

63. Pishdar, M.; Ghasemzadeh, F.; Antuchevičienè, J. A mixed interval type-2 fuzzy best-worst MACBETH approach to choose hub airport in developing countries: Case of Iranian passenger airports. Transport 2019, 34, 639-651. [CrossRef]

64. Lieb, K.J.; Lieb, R.C. Environmental sustainability in the third-party logistics (3PL) industry. Int. J. Phys. Distrib. Logist. Manag. 2010, 40, 524-533. [CrossRef]

65. Ferraro, T.; Pais, L.; Rebelo Dos Santos, N.; Moreira, J.M. The Decent Work Questionnaire: Development and validation in two samples of knowledge workers. Int. Labour Rev. 2018, 157, 243-265. [CrossRef]

66. Nazmul Islam, M.; Furuoka, F.; Idris, A. Mapping the relationship between transformational leadership, trust in leadership and employee championing behavior during organizational change. Asia Pac. Manag. Rev. 2020, in press. [CrossRef]

67. Kähkönen, T.; Blomqvist, K.; Gillespie, N.; Vanhala, M. Employee trust repair: A systematic review of 20 years of empirical research and future research directions. J. Bus. Res. 2021, 130, 98-109. [CrossRef]

68. Azadi, M.; Jafarian, M.; Farzippoor Saen, R.; Mirhedayatian, S.M. A new fuzzy DEA model for evaluation of efficiency and effectiveness of suppliers in sustainable supply chain management context. Comput. Oper. Res. 2015, 54, 274-285. [CrossRef]

69. Wanke, P.; Barros, C.P.; Nwaogbe, O.R. Assessing productive efficiency in Nigerian airports using Fuzzy-DEA. Transp. Policy 2016, 49, 9-19. [CrossRef]

70. Zadeh, L.A. The concept of a linguistic variable and its application to approximate reasoning. Inf. Sci. 1975, 8, 199-249. [CrossRef]

71. Hu, J.; Zhang, Y.; Chen, X.; Liu, Y. Multi-criteria decision-making method based on possibility degree of interval type-2 fuzzy number. Knowl. Based Syst. 2013, 43, 21-29. [CrossRef]

72. Abdullah, L.; Zulkifli, N. Integration of fuzzy AHP and interval type-2 fuzzy DEMATEL: An application to human resource management. Expert Syst. Appl. 2015, 42, 4397-4409. [CrossRef]

73. Charnes, A.; Cooper, W.W.; Rodes, E. Measuring the efficiency of decision making units. Eur. J. Oper. Res. 1978, 2, 429-444. [CrossRef]

74. Farrell, M.J. The Measurement of Productive Efficiency. J. R. Stat. Soc. 1957, 120, 253-281. [CrossRef]

75. Banker, R.D.; Charnes, A.; Cooper, W.W. Some Models for Estimating Technical and Scale Inefficiencies in Data Envelopment Analysis. Manag. Sci. 1984, 30, 1078-1092. [CrossRef]

76. Faramarzi, G.R.; Tavassoli, M.; Saen, R.F. Network DEA: A new Approach for determining component weights. Int. J. Manag. Sci. 2014, 9, 178-184. [CrossRef]

77. Tone, K.; Tsutsui, M. Network DEA: A Slack-Based Measure Approach. EUR. J. Oper. Res. 2009, 197, 243-252. [CrossRef]

78. Tone, K.; Tsutsui, M. Dynamic DEA with Network Structure: A Slack-Based Measure Approach. Omega 2014, 42, 124-131. [CrossRef]

79. Hieu Tran, T.; Mao, Y.; Nathanail, P.; Siebers, P.O. Integrating Slacks-based Measure of Efficiency and Super-efficiency in Data Envelopment Analysis. Omega 2019, 85, 156-165. [CrossRef] 
80. Nestle. Creating Shared Value and Sustainability Report 2020. 2020. Available online: https://www.nestle.com/sites/default/ files/2021-03/creating-shared-value-report-2020-en.pdf (accessed on 15 May 2021).

81. Dutta, P.; Talaulikar, S.; Xavier, V.; Kapoor, S. Fostering reverse logistics in India by prominent barrier identification and strategy implementation to promote circular economy. J. Clean. Prod. 2021, 294, 126241. [CrossRef] 